\title{
An evaluation of the contemporary status of pragmatics within the field of second language learning and teaching
}

\begin{abstract}
This paper aims to evaluate the current position of pragmatics in the field of second language acquisition (SLA) with focus on teaching of English as a foreign language (TEFL). First it attempts to reach an overall understanding of pragmatics by looking into its history and its main definitions in the relative literature. Building on this understanding, pragmatics is given a definition that suits the SLA paradigm, including second language learning and teaching (SLLT). Then the concept of pragmatic competence will be discussed and how it can be achieved. This paves the way for shedding light on the status of teaching of pragmatics within the field of SLA/TEFL. This will include its representation in published TEFL materials and the difficulties that face assessing pragmatic competence.
\end{abstract}

\section{Keywords}

Pragmatics, Second language acquisition, SLA, Teaching English, TEFL, Education, Linguistic competence

History and origin of Pragmatics

\section{$\underline{\text { Roots of Pragmatics }}$}

The research on pragmatics "has roots stretching into earlier centuries" (Barron, Gu and Steen, 2017, p1) "... that can be traced back to early classical traditions of rhetorics and stylistics" (Middeke et al., 2012, p. 435; also see Morris, 1938, p. 30). The justification of this statement lies in the definitions of the two aforementioned traditions. Rhetorics, according to Aristotle, is the "... means of persuasion ... in a given situation" (Andrews, 2012, p4, my emphsis). Stylistics can be defined as the "analysis of style in language and how this can vary according to ... context" (Jeffries and McIntyre, 2010, p1, my emphasis). It is noticed here that both rhetorics and stylistics respectively link language to a given situation or context, which is, arguably, the essence of pragmatics (pragmatics: Cambridge English Dictionary, no date; pragmatics: Oxford Dictionaries, no date; Loewen, 2015, p3; VanPatten and Benati, 2015, p164; Slabakova, 2016, p11).

\section{The birth and development of Pragmatics as a linguistic term}

According to Rose (2013), Bublitz and Norrick (2011), and Levinson (1983) it is the American philosopher Charles Morris (1901-79) to whom the first explicit reference to 'pragmatics' as a term in the field of linguistics is credited. He elected the word 'pragmatics' to be the name of the study of "the pragmatical dimension of semiosis" (Morris, 1938, p6, original italicisation). Jucker (2012, p497) adds that Morris incorporated the ideas of another American philosopher: Charles S. Peirce (1839-1914) into his theory of signs. Pierce coined the term pragmatism, which he later changed to pragmaticism, to refer to his account of meaning. He based his theory on older works, particularly, the works of the German philosopher Immanuel Kant (1724-1804) (Atkin, no date). Huang $(2014$, p2) claims that Morris, "borrowed" the term from the German word 'pragmatisch' used by Kant in his book Critique of Pure Reason, first published in 1781 (see Kant, 2005). By examining Critique of Pure Reason (translated), it becomes clear that, compared to Peirce, Kant did not introduce the term 'pragmatic' in a way that Morris could use, which weakens Huang's claim. A sounder account, would be that it is Pierce, and not Morris, who adopted Kant's term as explained above (cf. Parret, 1993, p1). 
In the same year of Morris's introduction of the term, 1938, the term was adopted by Rudolf Carnap, a leading philosopher and a major figure in the first half of the twentieth century. Carnap used the word in his book Foundations of Logic and Mathematics (1938) (Levinson, 1983, p1), which apparently furnished the term with more credibility and acceptance amongst linguists. About thirty years later, in the late 1960s, pragmatics "finally" managed to become a part of modern linguistics as a result of linguists exploring the 'phenomena of performance' and becoming interested in utterance meaning (Bublitz and Norrick, 2011, p2) and philosophers' efforts to deal with its problems, and “assailing" Chomsky's (see Chomsky, 2014) 1965 linguistic model (Levinson, 1983, p4). In the1970s, pragmatics became established as a field of research in linguistics (Traugott, 2008, p. 207 cited in Jucker and Taavitsainen, 2012, p6; Barron, Gu and Steen, 2017, p1) evolving, debatably, with more pace and variation than any other discipline of linguistics (Rajagopalan, 2009; Bublitz and Norrick, 2011). The 1970s also witnessed the first international conferences on pragmatics and the launch of the Journal of pragmatics (1977) (Jucker and Taavitsainen, 2013, p2). The first key text books on the topic were published in the late 70s and early 80s (ibid, 2013). In 1986 the International Pragmatics Association (IPrA) was founded (IPrA Home, no date). Searching Google Books Ngram viewer using the term 'pragmatics' appears to confirm the above timeline (see figure 1).

Figure 1 (Google Ngram Viewer: pragmatics, no date, my captions)

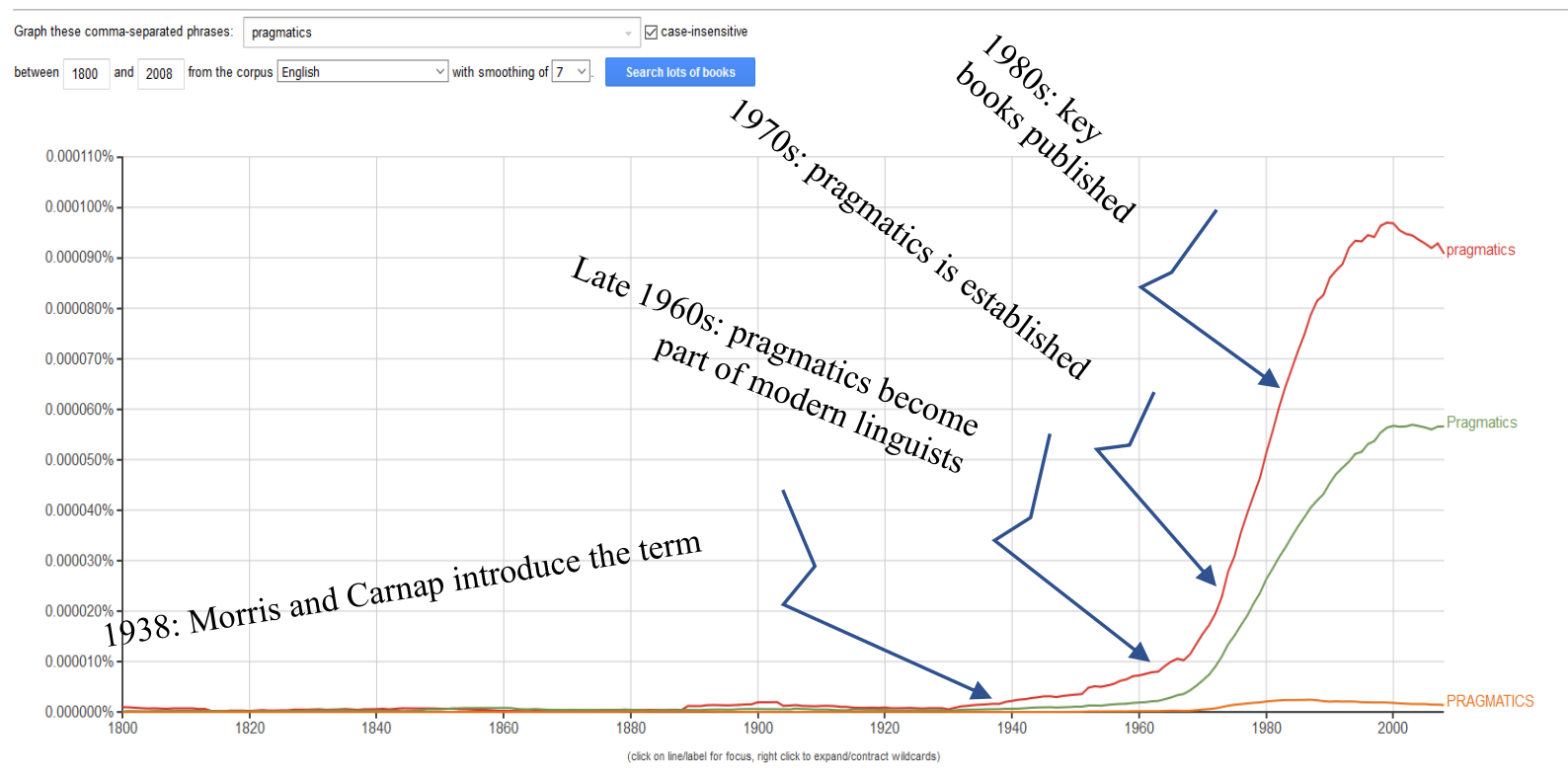

\section{Definitions of Pragmatics}

The expansion of pragmatics illustrated above, continues to this day, as Huang asserts. His assertion is consolidated by a survey of contemporary pragmatics in his introduction of The Oxford Dictionary of Pragmatics where he lists more than fifty of its branches (2012, p1-19). This combined with its relative recency (Jucker, 2012; Middeke et al., 2012; Jucker and Taavitsainen, 2013) and "early ... (... confusions) in Morris and Carnaps" (Searle, Kiefer and Bierwisch, 2012, pix, original brackets), have probably contributed to pragmatics being defined in numerous different ways (Peterwagner, 2005; Schneider, 2010, p240; Chapman, 2011, p1). Thus, leading eventually to the emergence of two major trends of studying pragmatics.

\section{The major trends of defining and studying pragmatics}

They can be geographically categorised as: The Continental-European tradition and Anglo-American tradition (Levinson, 1983; Parret, 1993; Leo, 2004; Huang, 2012). This categorisation is approximate and for "convenience" (Jucker, 2012, p508), since not every linguist from either tradition necessarily belongs geographically or "in spirit" to its "camp" (Verschueren, 2017, p124-125). The division between the two traditions is still upheld and reflected in many recent relevant textbooks and handbooks (Jucker and Taavitsainen, 2010; Jucker, 2012; Barron, Gu and Steen, 2017), which makes it worthy to discuss and evaluate each of these traditions. 
The Continental-European tradition. The Continental-European tradition, the "perspective view" (Huang, 2014, p5), or "social pragmatics" as Chapman (2011, p5) suggests, has a broad view of pragmatics (Jucker and Taavitsainen, 2012; Middeke et al., 2012; Barron, Gu and Steen, 2017). It sees it as a functional (Huang, 2014, p5), superordinate (Barron, Gu and Steen, 2017, p1) cognitive, social and cultural (Verschueren, 1999, p7) perspective. This perspective view (as Huang calls it) is applied to all aspects of linguistic behaviour including, "inter alia, language functions, maxims of communication, systems of knowledge, means and strategies of evaluation, principles of text and discourse organisation" (Middeke et al., 2012, p436, original italicisation). Furthermore, it encompasses all the core components of linguistics (Huang, 2010, p13, 2012, p1) and non-core branches of linguistics such as sociolinguists and psycholinguistics (Huang, 2012, p8). Additionally, it goes beyond linguistics and extends the research to "neighbouring fields such as sociology or psychology" (Barron, Gu and Steen, 2017, p1).

Criticism. This wide inclusivity of the Continental-European tradition was criticised. For example, Levinson (1983, p7) criticises its failure to distinguish pragmatics from "many other [linguistic] disciplines". Notably, Nuyts (1992, p66) refutes Levinson and considers this overlapping a "merit" that could enhance research. Similarly, Huang (2014) criticises the tradition and alleges that it "appears to be a study of "everything"" which, as he claims, the equivalent to studying "nothing". He adds that that this view "seems too inclusive to be of much theoretical significance". He is particularly critical of its overlapping with other linguistic fields and wonders "how a coherent research agenda can be made within" this wide view (p. 6). It is not far from reasonable to label this criticism unwarranted to say the least, especially given that, in the previous page, he maintains that the Continental-European tradition is "more faithful to the original view of pragmatics expressed by Morris" (ibid, 2014, p5). This almost amounts to a contradiction, since, according to him, the proponents of the Continental-European tradition were only building on the definition of pragmatics provided by none other than the founder himself: Morris.

The Anglo-American tradition. By way of contrast to the Continental-European, the AngloAmerican tradition, also referred to as the "component view" (Huang, 2014, p5) or the "theoretical approach" (Chapman, 2011, p5) is a narrow and focused approach that sees pragmatics as a core component of linguistics parallel to other core components of linguists such as phonetics, phonology, morphology, syntax, and semantics (Huang, 2010, p13; Jucker, 2012, p293; Barron, Gu and Steen, 2017, p1) or as an extension of semantics (Schneider, 2010, p240). Its domain comprises implicature, presupposition, speech acts, reference and deixis (Horn and Ward, 2006, pv; Huang, 2010, p13, 2017, pvi-vii; Yule, 2010, pix; Barron, Gu and Steen, 2017, p1). Definitions of these components will be provided below.

Interestingly, Culpeper and Haugh (2014, p6) attribute this tradition to Morris (cf. Huang, 2014). They claim that Morris took a "micro" view of context with no "social relations or situations". This claim, fairly clearly, overlooks that Morris states that pragmatics "deals with the biotic aspects of semiosis, that is, with all the psychological, biological, and sociological phenomena which occur in the functioning of signs" (1938, p30, my emphasis). In addition, Morris mentions the very word "social" later on the same page twice. Nonetheless, Morris seems to represent pragmatics as a component of linguistics besides syntax and semantics $(1938$, p6) which supports Culpeper and Haugh's contention. This leads to the pluasbile conclusion that both views of pragmatics have their roots in the Morrisian definition.

Criticism. Despite being based on Morris's definition, the Anglo-American tradition was criticised for "its failure to provide coherent theorizing" as Verschueren (2017, p124) reports. Moreover, in a style similar to Huang's (2014), Nuyts (1992, p66) considers the Anglo-American view of pragmatics as characterised by Levinson (1983) "nothing but a ... number of topics" and questions, again in a 'Huang's style', whether pragmatics within the Anglo-American tradition "can be seriously motivated as an independent field of inquiry” (cf. Huang's criticism of the Continental-European tradition above).

By examining the style in which criticisms of both traditions were delivered, a reasonable assertion could be risked that the way pragmatics is viewed has become an arena of conflict where defenders from both 'camps' would go as far as using demolishing phrases and failing to adhere to reason and logic. Nevertheless, the same arena is witnessing a "search for unity" (Verschueren, 2017, p126) from both sides to resolve the conflict by providing a coherent characterisation of the notion of pragmatics (Nuyts, 1992, 
p65), taking “an in-between position" (Schneider, 2010, p240), converging (Huang, 2012, p6), and introducing definitional coherence (Verschueren, 2017, p126). Evaluating these unifying efforts is beyond the bounds of this paper, since its main aim, besides telling the "success story of ... pragmatics" (Chapman, 2011, p13; Jucker and Taavitsainen, 2013, p5) is to reach a definition of pragmatics that is suited for the purpose of second language learning and teaching (SLLT).

\section{Defining Pragmatics as a teachable component within SLLT}

Hereafter, this paper will refer to pragmatics as viewed by the American-Anglo tradition. It is defined as the study of language use and meaning in a given situation or social context (pragmatics: Cambridge English Dictionary, no date; pragmatics: Oxford Dictionaries, no date; Loewen, 2015, p3; VanPatten and Benati, 2015, p164; Slabakova, 2016, p11). The rationale behind opting for this tradition is that it is more likely to suite SLLT purposes and pedagogy in general, since it views pragmatics as one of the components of linguistics. These components, such as syntax, which includes grammar, and phonology, which includes spelling, have been traditionally taught for centuries. In other words, pragmatics defined this way would not be a completely new concept to SLLT; it would be an addition to or extension of components already being taught (see Schneider, 2010, p240). Likewise, the American-Anglo tradition has a focused view and clearly identified components. These components include, inter alia, implicature ("what is meant in a[n] ... utterance without being ... said" (Horn, 2006, p3)), presupposition (information assumed to be true or known by a listener or reader (Yule, 2010, p133)), speech acts (acts performed by a speaker with an utterance (Searle, Kiefer and Bierwisch, 2012, pvii)), reference (acts used to enable a listener or reader to identify something (Yule, 2010, p131)), and deixis (words used to point to things, people, location or time (Yule, 2010, p130)), and inference ("a process of accepting a statement or proposition ... on the basis of the ... acceptance of one or more other statements or propositions" (Huang, 2012, p156)) (Horn and Ward, 2006, pv; Huang, 2010, p13, 2017, pvi-vii; Yule, 2010, pix; Barron, Gu and Steen, 2017, p1).

Predominance of speech acts within SLLT. As the given definitions show, most, if not all, of these components can be related to SLLT. However, according to Jeon and Kaya (2006) the most popular L2 targets of pragmatics teaching are speech acts. Their results were based on a research that combined the results of 34 relevant studies to produce better results, or, in short, a meta-analysis of these studies (metaanalysis: Cambrdige English Dictionary, no date). Furthermore, Roever (2009, p560) accentuates the predominance of research on speech acts. This justifies Bardovi-Harlig's (2001, p13) adopting "a speech act perspective" for her review since "speech act research has been well represented in ... pragmatics research, and provides a common analytic framework which facilitates comparison across studies". This paper will limit its focus to speech acts for the same reasons.

Speech acts are categorised into illocutionary acts such as making statement, asking questions, giving orders, describing, explaining, apologising, thanking, and congratulating, and perlocutionary acts which goes beyond the utterance, e.g. convincing, persuading, annoying, amusing, and frightening (Searle, Kiefer and Bierwisch, 2012). Most of, and possibly all, these speech acts can be turned into topics for SLLT with relatively clear learning objects and quantifiable outcomes with the aim of developing the learner's pragmatic skills and general second language ability.

\section{Pragmatic competence}

\section{Pragmatics competence within general language ability}

Language ability according to Bachman and Palmer (1996, p69-70) are divided into language competence and strategic competence, which is a set of metacognitive strategies. Language competence, or knowledge as Bachman and Palmer prefer to call it, involves two broad components: organisational and pragmatic competence. Organisational competence is concerned with recognising and producing grammatically acceptable oral and written texts. Pragmatic competence enables the learner to relate the language being used to its pragmatic meaning. It has two areas: functional competence and sociological competence. The former relates to interpreting utterances in the light of the utterers' intentions whereas the latter focuses on 
the appropriateness of the language produced in a given context (ibid, 1996, pp. 69-70). Bachman and Palmer devide these further into subcomponents. See Table 1.

Table 1 Areas of language knowledge. Based on Bachman \& Palmer (1996, p68), Table 4.1.

- Organizational knowledge

- Grammatical knowledge

- Knowledge of vocabulary

- Knowledge of syntax

○ Knowledge of phonology/graphology

- Textual knowledge

○ Knowledge of cohesion

- Knowledge of rhetorical or conversational organization

- Pragmatic knowledge

- Functional knowledge

- Knowledge of ideational functions

- Knowledge of manipulative functions

- Knowledge of heuristic functions

- Knowledge of imaginative functions

- Sociolinguistic knowledge

- Knowledge of dialects/varieties

- Knowledge of registers

- Knowledge of natural or idiomatic expressions

- Knowledge of cultural references and figures of speech

Other main models of linguistic competence, such as Canale and Swain (1980), Canale (1983), and Okvir (2005) (cited in Bagarić and Djigunović (2007)), agree with Bachman and Palmer's model; they recognise pragmatic competence as part of language ability and categorise it similarly (Bagarić and Djigunović, 2007; Abrams, 2014). This is another indication, besides the definition as discussed above, that research on pragmatics is moving towards uniformity.

\section{$\underline{\text { Achieving pragmatic competence with and without instruction }}$}

Pragmatic competence can be achieved, either with or without instruction. As an example of achieving pragmatic competence without instruction the case of Reigle (2011) would be considered. Drawing on her own experience in learning the Romanian language as an adult learner, she claims that reaching native-like pragmatic competence without instruction is possible through living in the target culture. She warns, nonetheless, it could be a difficult and even stressful experience and speaks of a 'cultural shock' that she experienced. Similar to Reigle's is the case of Julie. Julie lived in Egypt and "after $2 \frac{1}{2} 2$ years she was able to pass as a native speaker" of Egyptian Arabic (Ioup et al., 1994, p78). Although Julie's language competence was thoroughly assessed, the study does not mention explicitly that her pragmatic competence was assessed. However, the fact that she was able to pass as a native and her understanding of the culture as the study indicates (ibid, 1994, p78) suggests that she must have mastered the pragmatics of Egyptian Arabic. Interestingly, she also reported experiencing cultural shock.

Attaining pragmatic competence naturally is more possible in young learners under the critical age, estimated to be up to the age of 15 (Qureshi, 2016). Clark (2006) concludes that by age six, children already have pragmatic knowledge. They are capable of making inference (see the definition of inference above) and using polite forms correctly, amongst other abilities. Still, this knowledge needs enhancement and further development. Although this applies to L1, it is contended here, with Chomsky's concept of innate language knowledge, Krashen's (1982) monitory theory and the two adult cases discussed above in mind, that this conclusion can be applied to L2 young learners. To put this argument in other words, L2 young learners 
would be able to acquire native-like pragmatic competence in L2 without instruction if the exposure was sufficient.

Rose and Kwai-fun (2001), Ishihara (2004, 2007), Bardovi-Harlig and Velleng (2012), Nguyen, Pham and Pham (2012), and Abrams (2014) exemplified cases of teaching speech acts. These include: indirect complaints, apologies, requests, refusals, thanks and giving/responding to compliments, declining a request, expressing displeasure, pragmatic routines such as 'No problem' and 'Nice to meet you', and constructive criticism. The teaching and learning of these speech acts, in all the cases mentioned above, was through classroom-based formal instruction with positive results reported. These results lend support to the assertion that "instructional intervention may be facilitative to, or even necessary for, the acquisition of L2 pragmatic ability" (Kasper and Rose, 2001, p8) and without it EFL learners are often prone to serious pragmatic issues (Bardovi-Harlig, 2001, p28). Rose and Kwai-fun (2001) compared inductive and deductive approaches with positive results for both without any advantage of one over the other. The case studies mentioned within this paragraph show that explicit, implicit, inductive and deductive instructions can all be effective in teaching pragmatics. They also prove beyond doubt that pragmatics is teachable.

\section{Contemporary teaching of Pragmatics}

Despite being teachable, pragmatics as a topic "is not widely taught in any systematic way" because "methodological approaches ... tend to focus on grammar, vocabulary, and the four skills" (Roever, 2009, p568). Roever adds that even in "communicatively oriented language-teaching settings, pragmatic content would probably be addressed incidentally" which cannot be considered a "systematic attempt at designing a "pragmatic syllabus"'. This is confirmed by the findings of a content analysis on 17 course books by leading international publishers. The study concluded that although certain types of speech acts "were present in the course books analysed [in varying degrees,] ... pragmatic knowledge does not receive the attention it deserves from material developers and course book writers" (Aksoyalp and Toprak, 2014, p131). This seems to be increasingly realised by some publishers recently.

Interchange 1 fifth edition (student's book), published by Cambridge University Press (Richards, 2017), is part of an updated version of "the world's favorite [sic] English course ... that has been used by over 50 million students worldwide" (Cambridge English, 2017). Examining this book reveals that the speaking section within at least five units, out of a total of 16 units, contained contents that can be related to speech acts as in Table 2 .

Table 2 Units from Interchange $15^{\text {th }}$ edition that provide pragmatic instruction

\begin{tabular}{|l|l|}
\hline Unit & Speech acts that appear in the speaking section \\
\hline 1 & Introductions and greetings \\
\hline 4 & Talking about likes and dislikes; making invitations and excuses \\
\hline 12 & Asking for and giving suggestions \\
\hline 13 & Expressing likes and dislikes; agreeing and disagreeing \\
\hline 15 & Making invitations; Accepting and refusing invitations; \\
\hline
\end{tabular}

Besides English for general purposes (EGP), which Interchange belongs to, teaching of pragmatics can be found is in English for special purposes (ESP). For instance, HIGH SPEED TRAINING (no date), a training company based in the UK, offers an online Patient Customer Service course. Most of the content of the course falls within speech acts, especially module three and module four of the course. Some of the titles most related to pragmatics that these two modules cover are: politeness, explaining and apologising, being empathetic, and handling complaints. It is noteworthy that courses of this kind are a response to a real problem that the NHS faced with its overseas-trained doctors (OTDs) who had gaps in communication and pragmatic skills (Cheung, 2011; General Medical Council, 2011). 
Perhaps, one of the reasons that teaching of pragmatics is not widely practiced is that it is difficult to assess. An assessment of pragmatic competence would require establishing authentic contexts that emulate the real world which is a real challenge that could be resource-demanding and costly rendering it impractical (Roever, 2009, p572). Then there are the problems of the absence of any global proficiency measures for pragmatics (Bardovi-Harlig, 2013, p77); international tests such as IELTS and TOEFL do not explicitly assess pragmatic abilities. El Shazly (2017) in her PhD thesis expressed the dilemma that she faced when assessing the pragmatic abilities of her research sample. She resorted to a multi-method approach using a perception/recognition multiple-choice discourse completion task (MDCT), a production MDCT, an openended written discourse completion task, and self-reported diaries.

\section{Conclusion}

From all the aforementioned, it can be concluded that pragmatics being relatively a recent branch of linguistics has theoretical aspects and debates that have not completely settled yet. There are differences in the way it is defined amongst other issues. Even so, there are signs that it is moving toward unity in understanding and definition. Teaching of pragmatics would particularly benefit from defining it as an extensional component of SLA.

Research shows that pragmatic competence is achievable with instruction explicitly, implicitly, inductively and/or deductively. It can also be achieved without instruction. Yet, it has not reached its potential yet and is underrepresented in the field of SLA. It is still largely limited to speech acts. However, there is evidence that the scene is witnessing a recent trend to include pragmatics in TEFL materials. One of the main obstacles in the way of wide inclusion of pragmatics in teaching English is challenges that face the practicality and standardisation of assessing pragmatic competence. In addition, pragmatics is not currently explicitly included in English competence international tests.

\section{Recommendation and future research}

The debate that seeks unifying the definition of pragmatics within linguistics is likely to continue for some time. Nonetheless, theoretical background for teaching of pragmatics can still be founded if pragmatics is viewed (and researched) as a teachable subject. Without learning the pragmatics of the target language, its acquisition becomes deficient and incomplete if not impossible. However, there are challenges that face teaching of pragmatics. There is a need to research how assessment of pragmatic competence can be standardised and quantified. Additional research is needed to identify practical ways of including pragmatics in language teaching curriculums and materials.

\section{References:}

Abrams, Z.I. (2014). Using film to provide a context for teaching L2 pragmatics. System, 46 (Supplement C), 55-64. Available from https://doi.org/https://doi.org/10.1016/j.system.2014.06.005.

Aksoyalp, Y. and Toprak, T.E. (2014). Incorporating Pragmatics in English Language Teaching: To What Extent Do EFL Course Books Address Speech Acts? International Journal of Applied Linguistics \& English Literature, 4 (2). Available from https://doi.org/10.7575/aiac.ijalel.v.4n.2p.125.

Andrews, R. (2012). Introduction. In: Andrews, R., ed. Rebirth of Rhetoric. London: Routledge, 1-18.

Atkin, A. (no date). Charles Sanders Peirce: Pragmatism. The Internet Encyclopedia of Philosophy. Available from http://www.iep.utm.edu/peircepr/ [Accessed 22 December 2017].

Bachman, L.F. and Palmer, A.S. (1996). Language Testing in Practice: Designing and Developing Useful Language Tests, 1st ed. Oxford [u.a.]: Oxford University Press. Available from https://books.google.co.uk/books?id=E0yH0NdySrQC. 
Bagarić, V. and Djigunović, J.M. (2007). Defining communicative competence. Metodika, 8 (1), 94-103.

Bardovi-Harlig, K. (2001). Evaluating the empirical evidence: Grounds for instruction in pragmatics? In: Rose, K.R., and Kasper, G., eds. Pragmatics in Language Teaching. Cambridge: Cambridge University Press, 13-32. Available from https://doi.org/10.1017/CBO9781139524797.005 [Accessed 9 December 2017].

Bardovi-Harlig, K. (2013). Developing L2 Pragmatics. Language Learning, 63, 68-86. Available from https://doi.org/10.1111/j.1467-9922.2012.00738.x.

Bardovi-Harlig, K. and Vellenga, H.E. (2012). The effect of instruction on conventional expressions in L2 pragmatics. System, 40 (1), 77-89. Available from https://doi.org/10.1016/J.SYSTEM.2012.01.004 [Accessed 18 December 2017].

Barron, A., Gu, Y. and Steen, G. (2017). PRAGMATICS BROADLY VIEWED. In: Barron, A., Gu, Y., and Steen, G., eds. The Routledge Handbook of Pragmatics. New York: Routledge, 1-3.

Bublitz, W. and Norrick, N.R. (2011). Introduction: the burgeoning field of pragmatics. In: Bublitz, W., and Norrick, N.R., eds. Foundations of Pragmatics. Volume 1 of Handbooks of Pragmatics [HOPS]. Berlin [u.a.]: De Gruyter Mouton, 1-22.

Cambridge English. (2017). Interchange 5th Edition. Available from http://www.cambridge.org/gb/cambridgeenglish/catalog/adult-courses/interchange-5th-edition [Accessed 8 January 2018].

Carnap, R. (1938). Foundations of Logic and Mathematics. International Encyclopedia of Unified Science: Foundations of the Unity of Science, 1 (3), 139-214.

Chapman, S. (2011). Pragmatics, 1st ed. Basingstoke: Palgrave Macmillan.

Cheung, C.R. (2011). NHS induction and support programme for overseas-trained doctors. Medical Education, 45 (5), 531-532. Available from https://doi.org/10.1111/j.1365-2923.2011.03960.x.

Chomsky, N. (2014). Aspects of the Theory of Syntax. Cambridge [u.a.]: The MIT Press.

Clark, E. V. (2006). Pragmatics and Language Acquisition. In: Horn, L.R., and Ward, G., eds. The Handbook of Pragmatics. Malden [u.a.]: Blackwell Publishing Ltd, 562-577. Available from https://doi.org/10.1002/9780470756959.ch25.

Culpeper, J. and Haugh, M. (2014). Pragmatics and the English Language, 1st ed. London: Palgrave Macmillan.

Editorial Board. (1977). Journal of pragmatics. Journal of pragmatics, 1 (1).

El Shazly, R.F. (2017). The Role of Pragmatics Instruction in Language Learning in The Context of English as a Foreign Language.

General Medical Council. (2011). The state of medical education and practice in the UK. London. Available from https://www.gmc-uk.org/publications/10586.asp.

Google Ngram Viewer: pragmatics. (no date). Available from https://books.google.com/ngrams/ [Accessed 12 December 2017].

HIGH SPEED TRAINING. (no date). Online Patient Customer Service Training. Available from https://www.highspeedtraining.co.uk/business-skills/patient-customer-service-course.aspx [Accessed 8 
January 2018].

Horn, L.R. (2006). Implicature. In: Horn, L.R., and Ward, G., eds. The Handbook of Pragmatics. Malden [u.a.]: Blackwell Publishing, v--vii.

Horn, L.R. and Ward, G. (2006). Contents. In: Horn, L.R., and Ward, G., eds. The Handbook of Pragmatics. Malden [u.a.]: Blackwell Publishing, v-vii.

Huang, Y. (2010). Anglo-American and European Continental Traditions. In: Cummings, L., ed. The Routledge Pragmatics Encyclopedia. Abington: Routledge, 13-15.

Huang, Y. (2012). The Oxford dictionary of pragmatics, 1st ed. Oxford: Oxford University Press.

Huang, Y. (2014). Pragmatics, 2nd ed. Oxford [u.a.]: Oxford University Press.

Huang, Y. (2017). Content. In: Huang, Y., ed. The Oxford Handbook of Pragmatics. Oxford: Oxford University Press, vii-ix.

Ioup, G. et al. (1994). Reexamining the Critical Period Hypothesis. Studies in Second Language Acquisition, 16 (01), 73. Available from https://doi.org/10.1017/S0272263100012596.

IPrA Home. (no date). Available from https://ipra.uantwerpen.be/main.aspx ?c=*HOME\&n=1003 [Accessed 22 December 2017].

Ishihara, N. (2004). Exploring the immediate and delayed effects of formal instruction: Teaching giving and responding to compliments. MinneTESOL/WITESOL Joumal, 21, 37-70.

Ishihara, N. (2007). Web-based Curriculum for Pragmatics Instruction in Japanese as a Foreign Language: An Explicit Awareness-raising Approach. Language Awareness, 16 (1), 21-40. Available from https://doi.org/10.2167/la398.0.

Jeffries, L. and McIntyre, D. (2010). Stylistics, 1st ed. Cambridge [u.a.]: Cambridge University Press.

Jeon, E.-H. and Kaya, T. (2006). Effects of L2 instruction on interlanguage pragmatic development. In: Norris, J.M., and Ortega, L., eds. Synthesizing research on language learning and teaching. Amsterdam: John Benjamins, 165-212.

Jucker, A.H. (2012). Pragmatics in the history of linguistic thoughts. In: Allan, K., and Jaszczolt, K.M., eds. The Cambridge Handbook of Pragmatics. Cambridge Handbooks in Language and Linguistics. Cambridge: Cambridge University Press, 495-513.

Jucker, A.H. and Taavitsainen, I. (2010). Introduction. In: Jucker, A.H., and Taavitsainen, I., eds. Historical Pragmatics. Berlin [u.a.]: De Gruyter Mouton, 3-32.

Jucker, A.H. and Taavitsainen, I. (2012). Pragmatic Variables. In: Hernández-Campoy, J.M., and CondeSilvestre, J.C., eds. The Handbook of Historical Sociolinguistics. Chichester: Wiley-Blackwell, 293306.

Jucker, A.H. and Taavitsainen, I. (2013). English historical pragmatics, 1st ed. Edinburgh: Edinburgh University Press.

Kant, I. (2005). The Critique of Pure Reason, 1st ed. Cambridge: Cambridge University Press. Available from http://books.google.com/books?id=Mz9BrtLXWXMC.

Kasper, G. and Rose, K.R. (2001). Pragmatics in language teaching. In: Rose, K.R., and Kasper, G., eds. 
Pragmatics in Language Teaching. Cambridge: Cambridge University Press, 1-10. Available from https://doi.org/10.1017/CBO9781139524797.003 [Accessed 9 December 2017].

Krashen, S.D. (1982). Principles and practice in second langauge acquisition. Oxford: Pergamon.

Leo, H. (2004). Spanish pragmatics Whence, where, whither? In: Márquez-Reiter, R., and Placencia, M.E., eds. Current trends in the pragmatics of Spanish. Amsterdam: John Benjamins Publishing Company, 4-14.

Levinson, S.C. (1983). Pragmatics, 15th ed. Cambridge: Cambridge University Press.

Loewen, S. (2015). Introduction to instructed second language acquisition, 1st ed. New York: Routledge.

meta-analysis: Cambrdige English Dictionary. (no date). Available from https://dictionary.cambridge.org/dictionary/english/meta-analysis [Accessed 18 December 2017].

Middeke, M. et al. (2012). English and American Studies: Theory and Practice, 1st ed. Stuttgart [u.a.]: J. B. Metzler.

Morris, C.W. (1938). Foundations of the theory of signs, 3rd impr. Chicago: The University of Chicago Press.

Nguyen, T.T.M., Pham, T.H. and Pham, M.T. (2012). The relative effects of explicit and implicit formfocused instruction on the development of L2 pragmatic competence. Journal of Pragmatics, 44 (4), 416-434. Available from https://doi.org/10.1016/J.PRAGMA.2012.01.003 [Accessed 18 December 2017].

Nuyts, J. (1992). Aspects of a Cognitive-pragmatic Theory of Language: On Cognition, Functionalism, and Grammar, 1st ed. Amesterdam [u.a.]: John Benjamins Publishing.

Parret, H. (1993). The Aesthetics of Communication. Dordrecht: Springer Netherlands. Available from https://doi.org/10.1007/978-94-011-1773-9.

Peterwagner, R. (2005). What is the Matter with Communicative Competence?: An Analysis to Encourage Teachers of English to Assess the Very Basis of Their Teaching. Vienna: LIT Verlag Münster.

pragmatics: Cambridge English Dictionary. (no date). Available from https://dictionary.cambridge.org/dictionary/english/pragmatics [Accessed 2 December 2017].

pragmatics: Oxford Dictionaries. (no date). Available from https://en.oxforddictionaries.com/definition/pragmatics [Accessed 2 December 2017].

Qureshi, M.A. (2016). A meta-analysis: Age and second language grammar acquisition. System, 60, 147160. Available from https://doi.org/10.1016/J.SYSTEM.2016.06.001 [Accessed 21 December 2017].

Rajagopalan, K. (2009). Pragmatics Today: From a Component of Linguistics to a Perspective of Language. In: Fraser, B., and Turner, K., eds. Language in Life, and a Life in Language. Bingley: Emerald, 335342.

Reigle, L.J. (2011). The Role of Pragmatic Competence in Second Language Acquisition. All Graduate Plan $B$ and other Reports, (163). Available from http://digitalcommons.usu.edu/gradreports/163.

Richards, J.C. (2017). Interchange 1 student's book, 5th ed. Cambridge [u.a.]: Cambridge University Press.

Roever, C. (2009). Teaching and Testing Pragmatics. In: Long, M.H., and Doughty, C.J., eds. The 
Handbook of Language Teaching. Malden [u.a.]: Wiley-Blackwell.

Rose, K. (2013). Pragmatics. In: Robinson, P., ed. The Routledge Encyclopedia of Second Language Acquisition. New York: Routledge Ltd, 501-504.

Rose, K.R. and Kwai-fun, C.N. (2001). Inductive and deductive teaching of compliments and compliment responses. In: Rose, K.R., and Kasper, G., eds. Pragmatics in Language Teaching. Cambridge [u.a.]: Cambridge University Press, 145-170. Available from https://doi.org/10.1017/CBO9781139524797.013 [Accessed 9 December 2017].

Schneider, K.P. (2010). Variational pragmatics. In: Fried, M., Östman, J., and Verschueren, J., eds. Variation and Change: Pragmatic Perspectives. Amesterdam: John Benjamins Publishing, 239-260.

Searle, J., Kiefer, F. and Bierwisch, M. (2012). Introduction. In: Searle, J., Kiefer, F., and Bierwisch, M., eds. Speech Act Theory and Pragmatics. Dordrecht: Springer Science \& Business Media, vii-xii.

Slabakova, R. (2016). Second Language Acquisition, 1st ed. Oxford: Oxford University Press.

VanPatten, B. and Benati, A.G. (2015). Key terms in second language acquisition, 2nd ed. London: Bloomsbury.

Verschueren, J. (1999). Understanding pragmatics, 1st ed. London: Arnold.

Verschueren, J. (2017). Continental European Perspictive View. In: Huang, Y., ed. Oxford Handbook of Pragmatics. Oxford Handbook of Pragmatics. Oxford: Oxford University Press, 120-131.

Yule, G. (2010). The Study of Language, 4th ed. Cambridge [u.a.]: Cambridge University Press. 